\title{
Płuczka wiertnicza z dodatkiem pochodnych alkoholi tłuszczowych
}

\author{
Drilling mud with the addition of fatty alcohol derivatives
}

\author{
Zima Grzegorz \\ Instytut Nafty i Gazu - Państwowy Instytut Badawczy
}

\begin{abstract}
STRESZCZENIE: W artykule przedstawiono wyniki badań nad opracowaniem płuczek wiertniczych zawierających pochodne alkoholi thuszczowych, które zapewnią uzyskanie ich optymalnych właściwości inhibitacyjnych w warunkach otworowych. W składach płuczek zostały zastosowane alkoksylowe pochodne alkoholi tłuszczowych, które są środkami niejonowymi i ich inhibitacyjne właściwości zostały potwierdzone we wcześniej przeprowadzonych badaniach. Płuczki o opracowanych składach zostały poddane badaniom w warunkach HPHT oraz obecności skażeń chemicznych i wzrastającej zawartości fazy stałej. Ze względu na możliwość zastosowania płuczek zawierających nowe rodzaje inhibitorów do dowiercania złóż, przeprowadzono również badania ich wpływu na uszkodzenie przepuszczalności skał zbiornikowych. Zastosowanie nowego rodzaju inhibitora wymagało opracowania metodyki kontrolowania jego zawartości w płuczce oraz metodyki obróbki płuczki w czasie wiercenia. Dotychczas stosowane tego typu inhibitory to tzw. poliglikole, będące polimerami tlenku etylenu lub kopolimerami tlenku etylenu i tlenku propylenu różniące się masą cząsteczkową. Głównym badaniem potwierdzającym inhibitacyjne właściwości płuczek jest badanie dyspersji skały ilastej, standardowo przeprowadzane w warunkach otoczenia. W niniejszym artykule opisano badania dyspersji w warunkach podwyższonej temperatury celem potwierdzenia właściwości inhibitacyjnych badanych środków w warunkach zbliżonych do otworowych. Badania dyspersji powiązano dodatkowo z pomiarami pęcznienia, czyli przyrostu objętościowego skały ilastej w środowisku płuczek wiertniczych. Przeprowadzono również badania płuczek zawierających nowe rodzaje poliglikoli w warunkach otworopodobnych: wykonano badania odporności tych płuczek na skażenie jonami metali dwuwartościowych $\left(\mathrm{Ca}^{2+} \mathrm{i} \mathrm{Mg}^{2+}\right)$, skażenie fazą stałą (zmielonym łupkiem mioceńskim imitującym zwierciny) oraz działanie podwyższonej temperatury. Przedstawiona w artykule tematyka jest wynikiem niesłabnącego zainteresowania ze strony przemysłu stosowaniem płuczek z dodatkiem tego typu inhibitorów. Środki te posiadają podobne właściwości do dotychczas stosowanych poliglikoli, ale wykazują większą efektywność w warunkach otworowych.
\end{abstract}

Słowa kluczowe: płuczka wiertnicza, poliglikol, uszkodzenie przepuszczalności, alkohol tłuszczowy.

ABSTRACT: The article presents the results of research on the development of drilling muds containing derivatives of fatty alcohols, which will ensure that their optimal inhibitory properties in borehole conditions are achieved. In the mud compositions, alkoxy derivatives of fatty alcohols were used, which are non-ionic agents and their inhibitory properties have been confirmed in earlier studies. Drilling fluids were tested under HPHT conditions as well as under conditions of chemical contamination and increasing solids content. Due to the possibility of using muds containing new types of inhibitors to drill-in, studies on their effect on damage to reservoir rock permeability were also conducted. The use of a new type of inhibitor required the development of a methodology for controlling its content in the mud and a method for treating the mud during drilling. Previously used inhibitors of this type are polyglycols that are polymers of ethylene oxide or copolymers of ethylene oxide and propylene oxide differing in molecular weight. The main test confirming the inhibitory properties of scrubbers is the testing of clay rock dispersion, normally carried out under ambient conditions. This article describes dispersion studies under elevated temperature conditions to confirm the inhibitory properties of test agents under conditions similar to wellbore. Dispersion studies were additionally associated with swelling measurements, i.e. volumetric growth of clay rock in the drilling mud environment. Muds containing new types of polyglycols were also tested in borehole-like conditions: tests on the resistance of these muds to divalent metal ions $\left(\mathrm{Ca}^{2+}\right.$ and $\left.\mathrm{Mg}^{2+}\right)$, solid phase contamination (ground Miocene shale imitating drill cuttings) and increased temperature. The subject matter presented in the article is the result of industry interest in the use of muds with the addition of this type of inhibitors. These agents have similar properties to the previously used polyglycols, but show greater efficiency under well conditions.

Key words: drilling mud, polyglycol, permeability damage, fatty alcohol.

Autor do korespondencji: G. Zima, e-mail: grzegorz.zima@inig.pl

Artykuł nadesłano do Redakcji: 05.12.2019 r. Zatwierdzono do druku: 26.02.2020 r. 


\section{Wstęp}

Składnikiem płuczek glikolowo-potasowych odpowiedzialnym za nadanie jej właściwości inhibitacyjnych jest środek chemiczny typu poliolu. Obecnie stosowane poliglikole są najczęściej polimerami uzyskanymi na drodze polimeryzacji tlenku etylenu lub kopolimerami tlenku etylenu i tlenku propylenu. Przemysł chemiczny oferuje dużą gamę środków różniących się masą cząsteczkową, rodzajem i proporcją użytych do polimeryzacji monomerów oraz sposobem ich połączenia. We wcześniejszych badaniach uzyskano pozytywne wyniki w zakresie zastosowania alkoksylowych pochodnych alkoholi tłuszczowych jako środków ograniczających hydratację skał, a dwa polimery tego typu zostały opatentowane. Pochodne alkoholi tłuszczowych będące przedmiotem artykułu wykazują wysoką zdolność ograniczania hydratacji skał w szerokim zakresie temperatur otworowych. Natomiast w przypadku większości dotychczas stosowanych środków ich właściwości inhibitacyjne maleją wraz ze wzrostem temperatury. W artykule przedstawiono wyniki badań doboru dotychczas niestosowanych w technologii płuczkowej polioli, które zapewniają uzyskanie optymalnych właściwości inhibitacyjnych płuczek wiertniczych w szerokim zakresie temperatury. Nowe środki zostały sprawdzone w składach płuczek wiertniczych, w celu potwierdzenia ich właściwości inhibitacyjnych oraz określenia ich wpływu na filtrację i parametry reologiczne w temperaturze otoczenia oraz w warunkach HPHT.

\section{Część teoretyczna}

Płuczka glikolowo-potasowa zaliczana jest do płuczek o podwójnym inhibitowaniu jonowo-polimerowym. Funkcję inhibitora polimerowego w tej płuczce spełnia niejonowy polimer - poliglikol, $\mathrm{KCl}$ jest inhibitorem jonowym. Beziłowa płuczka glikolowo-potasowa ze względu na małe uszkodzenie przepuszczalności skał zbiornikowych może być stosowana do dowiercania poziomów produktywnych. Inhibitujące działanie płuczki na skały ilaste tłumaczy się przenikaniem powstających w podwyższonej temperaturze i mineralizacji kropelek poliglikolu do por skał i wiązaniem poliglikolu z iłem za pomocą wiązań wodorowych. Poliglikol przenikając do por skały wypiera z nich wodę i tym samym ogranicza ich hydratację. Tworzy on również powłokę adsorpcyjną na powierzchni skały i tym samym ogranicza szybkość hydratacji. Istotną rolę w procesie inhibitacji przez poliglikol odgrywają również jony $\mathrm{K}^{+}$na skutek synergetycznego oddziaływania z poliglikolem (Aston i Eliot, 1994; Reid et al. 1995; Bielewicz i Bortel 2000; Queiroz i Santos 2000; Balaban et al., 2015; Jasiński, 2015, 2016).
W warunkach otworowych dochodzi do obniżenia wartości parametrów reologicznych i wzrostu filtracji płuczki wiertniczej. Jest to skutkiem zmian fizycznych zachodzących w płuczce pod wpływem temperatury lub degradacji polimerów „odpowiedzialnych" za nadawanie płuczce odpowiednich parametrów reologicznych i ograniczanie filtracji. W pierwszym przypadku jest to proces odwracalny. W przypadku degradacji polimeru konieczna jest natomiast ciągła obróbka płuczki przez dodatek kolejnych porcji polimeru. Z degradacją polimeru mamy do czynienia szczególnie w przypadku równoczesnego występowania podwyższonej temperatury i skażeń

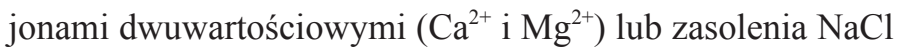
i KCl. Przewiercane skały mogą wywoływać skażenie płuczki. Przez materiał skażający rozumiemy dowolny materiał posiadający szkodliwy wpływ na fizyczne i chemiczne właściwości płuczki wiertniczej. Głównym czynnikiem skażającym płuczkę jest faza stała pochodząca z przewiercanych warstw (Oort et al., 1997; Bielewicz i Bortel, 2000; Lange i Keilhofer, 2004; Zamora et al., 2013; Leonhardt et al., 2014; Sayindla et al., 2017; Zhu et al., 2017; Razali et al., 2018).

Niekorzystny wpływ na płuczkę wiertniczą mają również jony wapnia i magnezu przedostające się z przewiercanych warstw lub dopływających solanek złożowych. Istnieje możliwość reakcji jonów dwuwartościowych $\left(\mathrm{Ca}^{2+} \mathrm{i} \mathrm{Mg}^{2+}\right) \mathrm{z}$ polimerami stosowanymi do sporządzania płuczek czego skutkiem może być obniżenie lepkości i podwyższenie filtracji. Jony dwuwartościowe mają również niekorzystny wpływ na stosowane w składach płuczek środki powierzchniowo czynne, które w wyniku reakcji z nimi tworzą nierozpuszczalne osady. Do skażenia jonami dwuwartościowymi dochodzi głównie podczas przewiercania anhydrytu $\left(\mathrm{CaSO}_{4}\right)$, gipsu $\left(\mathrm{CaSO}_{4} \cdot 2 \mathrm{H}_{2} \mathrm{O}\right)$ oraz cementu i karnalitu $\left(\mathrm{KMgCl}_{3} \cdot 6 \mathrm{H}_{2} \mathrm{O}\right)$. Podczas przewiercania halitu $(\mathrm{NaCl})$ i sylwinu $(\mathrm{KCl})$ również mamy do czynienia z niekorzystnym oddziaływaniem na płuczkę - objawia się to głównie wzrostem filtracji. Mogą towarzyszyć temu również zmiany parametrów reologicznych - często dochodzi do obniżenia lepkości lub do znacznego wzrostu granicy płynięcia i wytrzymałości strukturalnej. Płuczki stosowane do przewiercania halitu i sylwinu powinny zawierać w swoim składzie odpowiednią koncentracje tych soli tj. $\mathrm{NaCl}$ i $\mathrm{KCl}$, aby zapobiec rozpłukiwaniu przewiercanych warstw i tworzeniu się kawern (van Oort et al., 1997; Bielewicz i Bortel, 2000; Taugbol et al., 2005; Khodia et al., 2010; Kulawardana et al., 2012; Sayindla et al., 2017; Zhu et al., 2017; Gholami et al., 2018; Razali et al., 2018).

Łupki są skałami osadowymi powstałymi na skutek sedymentacji na dnach mórz i oceanów. Zbudowane są z różnych minerałów różniących się strukturalnie. Niektóre z tych minerałów łatwo ulegają hydratacji, należą do nich łupki typu montmorylonitu. Minerał ten występuje zwykle na niewielkich 
głębokościach. Ze wzrostem głębokości jego zdolność do hydratacji maleje z powodu niszczenia wewnętrznej struktury. Utrzymanie stabilności ściany otworu podczas przewiercania łupków jest podstawowym problemem w wierceniach w rejonie Karpat. Ponadto przyczyną trudności przy przewiercaniu łupków może być występowanie w nich gazu. Brak stabilności ściany otworu powoduje wiele trudności w czasie wiercenia, między innymi: powoduje przychwycenia przewodu wiertniczego, trudności z oczyszczaniem otworu, zwiększenie objętości płuczki, przyczynia się do pogorszenia jakości cementowania oraz stwarza trudności podczas prac geofizycznych. Przyczyną tych trudności jest głównie zjawisko hydratacji, tj. wzrostu uwodnienia łupków prowadzące do osłabienia wytrzymałości mechanicznej skał. Na ograniczenie zjawiska hydratacji skał możemy wpływać poprzez regulowanie właściwości płuczki wiertniczej w kierunku obniżenia filtracji i zastosowania w jej składzie odpowiednich inhibitorów hydratacji skał (Bielewicz i Bortel, 2000; Jasiński, 2015, 2016, 2017; Luyster et al., 2016; Zhu et al., 2017).

Związki chemiczne zawierające w swojej budowie łańcuch polieterowy będący produktem kondensacji tlenku etylenu i tlenku propylenu zaliczane są do substancji powierzchniowo czynnych niejonowych. Tego typu związki mogą powstawać w wyniku kondensacji tlenku etylenu i tlenku propylenu lub ich kondensacji z związkami posiadającymi czynny atom wodoru, takie jak np. alkohole i kwasy karboksylowe. Jest to jedna z najważniejszych grup związków powierzchniowo czynnych, które znajdują szerokie zastosowanie (Ogonowski i Tomaszkiewicz-Potempa, 1999).

W roztworach wodnych produkty te uzyskują słaby charakter kationowy, co jest związane z możliwością tworzenia wiązań wodorowych między atomami tlenu grup etoksylowych a cząsteczkami wody. Zjawisko to jest również odpowiedzialne za dobrą rozpuszczalność tych związków w wodzie. Charakterystyczną właściwością tych surfaktantów jest obniżenie ich rozpuszczalności w wodzie ze wzrostem temperatury. Obniżenie rozpuszczalności objawia się zmętnieniem ich wodnych roztworów i związane jest ze zmniejszeniem trwałości wodorotlenków oksoniowych. Sprzyja temu również dodatek elektrolitów. Temperatura mętnienia jest jedną z wielkości charakteryzujących ten typ surfaktantów. Zmieniając stopień etoksylowania możemy regulować właściwości otrzymywanych produktów (Ogonowski i Tomaszkiewicz-Potempa, 1999; van Oort, 2003; Villabona-Estupinan et al., 2017).

Niejonowe surfaktanty tego typu charakteryzują się niską wartością krytycznego stężenia micelarnego, które jest 10-100-krotnie niższe niż dla surfaktantów anionowych. Ta właściwość umożliwia ich efektywne stosowanie w znacznie niższych stężeniach niż np. surfaktanty anionowe. Niejonowe surfaktanty charakteryzują się ponadto niską zdolnością pienienia, co jest ważną właściwością przy zastosowaniu do prania mechanicznego i przemysłowego oraz jako składników płuczek wiertniczych (Ogonowski i Tomaszkiewicz-Potempa, 1999; Bielewicz i Bortel, 2000; Kania et al., 2018).

Do surowców najczęściej poddawanych etoksylowaniu należą alkohole tłuszczowe, alkilofenole, aminy, amidy i tłuszcze. Addycja tlenku propylenu do alkoholu tłuszczowego jest równoznaczna z przedłużeniem łańcucha hydrofobowego, dlatego produkty tej reakcji poddaje się ponownie reakcji z tlenkiem etylenu w celu poprawy rozpuszczalności w wodzie. Obecność w łańcuchu merów pochodzących od tlenku propylenu jest ważna ze względu na obniżenie zdolności pianotwórczych przy zachowaniu pozostałych właściwości na dotychczasowym poziomie. Odwrócenie kolejności przyłączania tych grup powoduje obniżenie właściwości pianotwórczych, lecz znacznie obniża właściwości użytkowe tych związków (Ogonowski i Tomaszkiewicz-Potempa, 1999). Istnieje również możliwość zwiększenia hydrofobowości oksyetylenowanych alkoholi tłuszczowych przez zastąpienie końcowego atomu wodoru grupą alkilową lub arylową. Produkty tego typu są znane w handlu pod nazwą Marlox B i zostały wprowadzone na rynek przez niemiecką firmę Huls AG. Produkty te odznaczają się unikatowo niską zdolnością do pienienia.

Kopolimery tlenku etylenu i tlenku propylenu oraz pochodne polioksyetylenowe i polioksypropylenowe związków organicznych znajdują zastosowanie w płuczkach wiertniczych jako inhibitory hydratacji skał (van Oort, 1997; Khodja et al., 2010; Balaban et al., 2015; Zhang et al., 2015; Ferreira et al., 2016; He et al., 2016; Villabona-Estupinan et al., 2017; $\mathrm{Xu}$ et al., 2017; Gholami et al., 2018; Kazemi-Beydokhti i Hajiabadi, 2018).

W publikacjach (Samaei et al., 2007; Khodja et al., 2010; Xu et al., 2017) autorzy zwracają uwagę na znaczne zwiększenie szybkości wiercenia przy zastosowaniu płuczki glikolowej i doskonałe właściwości inhibitacyjne. Innym typem związków wykorzystywanym jako inhibitory hydratacji skał ilastych mogą być alkoksylowe pochodne glicerolu (Ferreira et al., 2016). Autorzy publikacji wskazują na podobne właściwości tych związków do polioli stosowanych jako inhibitory hydratacji skał. Związki te wykazują również synergizm działania z KCl, a mechanizm działania jest taki sam jak poliglikolu. Inhibitacyjne właściwości tych oligomerów potwierdzono testami oddziaływania na zawiesiny bentonitu oraz za pomocą fotografii wykonanych skaningowym mikroskopem elektronowym. Zdolność do ograniczania hydratacji skał ilastych przez poliglikole potwierdzili również autorzy (Balaban et al., 2015) za pomocą pomiarów czasu kapilarnej nasiąkliwości i pęcznienia skał ilastych. Związki z grupy polioli jako składniki płuczek mogą również ograniczać powstawanie spękań 
skał w czasie wiercenia i wpływać na stateczność ściany otworu (Zhang et al., 2015; He et al., 2016).

Drugie ważne zastosowanie związków poliolowych w płuczkach jest związanie z ich zdolnością do adsorbowania się na powierzchniach metalowych. Związki te wykazują zdolność do obniżania współczynnika tarcia na kontakcie metal-metal i metal-skała (Akram et al., 2016; Aziz et al., 2016; Sayindla et al., 2017; Xiao et al., 2017; Zhao et al., 2017; Kania et al., 2018). Polimery tlenku propylenu wykazują zdolność obniżania współczynnika tarcia (Xiao et al., 2017). Najbardziej efektywnym okazał się glikol polipropylenowy o najniższej masie cząsteczkowej 200 u. Autorzy wskazują na decydujący wpływ ilości grup $\mathrm{OH}$ w związku na właściwości smarne. W związku z tym polimery o najniższej masie cząsteczkowej ze względu na największą ilość grup $\mathrm{OH}$ powodują najbardziej efektywne obniżenie współczynnika tarcia. Najbardziej optymalna wartość pH dla uzyskania pożądanych właściwości smarnych płuczki wynosi 8 . Niejonowe estry polioli wykazują zdolność obniżania współczynnika tarcia na kontakcie metal-metal oraz mogą być stosowane do obniżania parametrów reologicznych płuczek (Kania et al., 2018). Środki te są efektywne przy koncentracji w płuczkach wiertniczych wynoszącej $1 \%$.

\section{Badania nad metodyką kontrolowania właściwości płuczek wiertniczych}

We wstępnych badaniach sporządzono płuczki wiertnicze na osnowie koloidu typu skrobiowego i biopolimeru ksantan, do których wprowadzano standardową ilość poliglikolu, tj. płuczki zawierające 4\% OL200 lub OL2024. W składach płuczek zastosowano również mieszaniny poliglikoli z emulgatorem, w taki sposób, że suma dodatku tych środków wynosiła również 4\%. We wcześniejszych badaniach prowadzonych w INiG - PIB stwierdzono korzystne działanie dodatku emulgatora na inhibitacyjne właściwości płuczek z dodatkiem OL200 lub OL2024 w temperaturach poniżej $50^{\circ} \mathrm{C}$.

Przeprowadzono badania nad możliwością obróbki i kontrolowania parametrów płuczek o opracowanych składach. W tym celu kolejno do płuczki wprowadzano zwierciny, chlorki wapnia i magnezu oraz wygrzewano w autoklawach przez 16 godzin w temperaturze $120^{\circ} \mathrm{C}$. Opisany cykl badań przedstawiono dla poszczególnych płuczek w tabelach 1-4. W czasie badania dodatkowo określono zawartość poliglikolu metodą ekstrakcyjną przed i po wprowadzeniu zwiercin. W ten sposób określono ilość poliglikolu, która zaadsorbowała się na zwiercinach. Następnie uzupełniono zawartość

Tabela 1. Wpływ skażeń fazą stałą i solami metali dwuwartościowych oraz temperatury na właściwości płuczek z dodatkiem OL200

Table 1. The influence of temperature, solid phase and divalent metal salts contamination on the properties of the muds containing OL200

\begin{tabular}{|c|c|c|c|c|c|c|c|c|c|c|c|}
\hline \multirow{3}{*}{$\begin{array}{c}\mathrm{Nr} \\
\text { płuczki }\end{array}$} & \multirow{3}{*}{\multicolumn{2}{|c|}{$\begin{array}{c}\text { Skład płuczki } \\
{[\%]}\end{array}$}} & \multirow{3}{*}{$\begin{array}{c}\text { Gęstość } \\
\rho \\
{\left[\mathrm{kg} / \mathrm{m}^{3}\right]}\end{array}$} & \multicolumn{2}{|c|}{ Lepkość } & \multirow{3}{*}{$\begin{array}{c}\begin{array}{c}\text { Granica } \\
\text { płynięcia } \\
\tau y\end{array} \\
{[\mathrm{~Pa}]}\end{array}$} & \multicolumn{2}{|c|}{$\begin{array}{l}\text { Wytrzymałość } \\
\text { strukturalna }\end{array}$} & \multirow{3}{*}{$\begin{array}{c}\text { Filtracja } \\
{\left[\mathrm{cm}^{3}\right]}\end{array}$} & \multirow{3}{*}{ pH } & \multirow{3}{*}{$\begin{array}{c}\text { Zawartośćc } \\
\text { poliglikolu }\end{array}$} \\
\hline & & & & $\eta p l$ & $\eta s$ & & I & II & & & \\
\hline & & & & \multicolumn{2}{|c|}{$[\mathrm{mPa} \cdot \mathrm{s}]$} & & \multicolumn{2}{|c|}{$[\mathrm{Pa}]$} & & & \\
\hline 1 & $\begin{array}{l}\text { Biocyd } \\
\text { Skrobia kleikowana } \\
\text { Biopolimer } \\
\text { KCl } \\
\text { Blokator węglanowy } \\
\text { OL200 }\end{array}$ & $\begin{array}{c}0,1 \\
3 \\
0,3 \\
7 \\
7 \\
4\end{array}$ & 1070 & 20 & 32,5 & 9,6 & 2,1 & 3,8 & 13,2 & 9,3 & 3,98 \\
\hline 2 & $\begin{array}{l}\text { Płuczka } 1 \\
+ \text { zwierciny } \\
+\mathrm{NaOH}\end{array}$ & 10 & 1130 & 24 & 40 & 15,3 & 2,7 & 5,4 & 2,0 & 9,3 & 2,97 \\
\hline 3 & $\begin{array}{l}\text { Płuczka } 2 \\
+ \text { OL200 }\end{array}$ & 1 & 1130 & 22 & 33 & 10,5 & 1,5 & 3,7 & 1,6 & 9,0 & 3,91 \\
\hline 4 & $\begin{array}{l}\text { Płuczka } 3 \\
+\mathrm{CaCl}_{2} \\
+\mathrm{NaOH}\end{array}$ & 4 & 1140 & 23 & 33 & 9,6 & 1,4 & 4,0 & 0,8 & 9,2 & $\mathrm{bp}$ \\
\hline 5 & $\begin{array}{l}\text { Płuczka } 4 \\
+\mathrm{MgCl}_{2} \\
+\mathrm{NaOH}\end{array}$ & 1 & 1140 & 23 & 32 & 8,6 & 1,0 & 2,7 & 0,4 & 9,2 & $\mathrm{bp}$ \\
\hline 6 & $\begin{array}{l}\text { Płuczka } 5 \\
\text { Wygrzewanie temp. } 120^{\circ} \mathrm{C} \\
+\mathrm{NaOH}\end{array}$ & & 1140 & 19 & 26 & 6,7 & 1,0 & 2,2 & 2,0 & 9,2 & $\mathrm{bp}$ \\
\hline 7 & $\begin{array}{l}\text { Płuczka } 6 \\
\text { + skrobia kleikowana } \\
\text { + biopolimer }\end{array}$ & $\begin{array}{l}1,5 \\
0,1\end{array}$ & 1140 & 34 & 48,5 & 13,9 & 2,4 & 7,2 & 0,4 & 9,5 & $\mathrm{bp}$ \\
\hline
\end{tabular}




\section{NAFTA-GAZ}

Tabela 2. Wpływ skażeń fazą stałą i solami metali dwuwartościowych oraz temperatury na właściwości płuczek z dodatkiem OL200 i emulgatora

Table 2. The influence of temperature, solid phase and divalent metal salts contamination on the properties of the muds containing OL200 and emulsifier

\begin{tabular}{|c|c|c|c|c|c|c|c|c|c|c|c|}
\hline \multirow{3}{*}{$\begin{array}{c}\mathrm{Nr} \\
\text { płuczki }\end{array}$} & \multirow{3}{*}{\multicolumn{2}{|c|}{$\begin{array}{c}\text { Skład płuczki } \\
{[\%]}\end{array}$}} & \multirow{3}{*}{$\begin{array}{c}\text { Gęstość } \\
\rho\end{array}$} & \multicolumn{2}{|c|}{ Lepkość } & \multirow{3}{*}{$\begin{array}{c}\text { Granica } \\
\text { płynięcia } \\
\tau y \\
{[\mathrm{~Pa}]}\end{array}$} & \multicolumn{2}{|c|}{$\begin{array}{l}\text { Wytrzymałość } \\
\text { strukturalna }\end{array}$} & \multirow{3}{*}{$\begin{array}{c}\text { Filtracja } \\
{\left[\mathrm{cm}^{3}\right]}\end{array}$} & \multirow{2}{*}{ pH } & \multirow{2}{*}{$\begin{array}{l}\text { Zawartość } \\
\text { poliglikolu }\end{array}$} \\
\hline & & & & $\eta p l$ & $\eta s$ & & I & II & & & \\
\hline & & & & \multicolumn{2}{|c|}{$[\mathrm{mPa} \cdot \mathrm{s}]$} & & \multicolumn{2}{|c|}{$[\mathrm{Pa}]$} & & & {$[\%]$} \\
\hline 1 & $\begin{array}{l}\text { Biocyd } \\
\text { Skrobia kleikowana } \\
\text { Biopolimer } \\
\mathrm{KCl} \\
\text { Blokator węglanowy } \\
\text { OL200 } \\
\text { emulgator }\end{array}$ & $\begin{array}{c}0,1 \\
3 \\
0,3 \\
7 \\
7 \\
4 \\
1\end{array}$ & 1070 & 23 & 32 & 8,6 & 1,4 & 3,4 & 9,6 & 9,3 & 3,63 \\
\hline 2 & $\begin{array}{l}\text { Płuczka } 1 \\
+ \text { zwierciny } \\
+\mathrm{NaOH}\end{array}$ & 10 & 1130 & 26 & 33,5 & 12,0 & 1,7 & 5,1 & 1,6 & 9,4 & 2,67 \\
\hline 3 & $\begin{array}{l}\text { Płuczka } 2 \\
+ \text { OL200 } \\
\text { + emulgator }\end{array}$ & $\begin{array}{c}1 \\
0,4\end{array}$ & 1130 & 24 & 32,5 & 8,1 & 1,0 & 4,1 & 1,0 & 9,0 & 3,94 \\
\hline 4 & $\begin{array}{l}\text { Płuczka } 3 \\
+\mathrm{CaCl}_{2} \\
+\mathrm{NaOH}\end{array}$ & 4 & 1140 & 24 & 35 & 10,5 & 1,3 & 3,8 & 0,8 & 9,1 & bp \\
\hline 5 & $\begin{array}{l}\text { Płuczka } 4 \\
+\mathrm{MgCl}_{2} \\
+\mathrm{NaOH}\end{array}$ & 1 & 1140 & 26 & 37 & 10,5 & 1,1 & 3,1 & 0,4 & 9,3 & bp \\
\hline 6 & $\begin{array}{l}\text { Płuczka } 5 \\
\text { Wygrzewanie temp. } 120^{\circ} \mathrm{C} \\
+\mathrm{NaOH}\end{array}$ & & 1140 & 23 & 31 & 7,7 & 1,2 & 3,7 & 1,2 & 9,2 & $\mathrm{bp}$ \\
\hline 7 & $\begin{array}{l}\text { Płuczka } 6 \\
+ \text { skrobia kleikowana } \\
\text { + biopolimer }\end{array}$ & $\begin{array}{l}1,5 \\
0,1\end{array}$ & 1140 & 43 & 61 & 17,2 & 2,9 & 11,0 & 0,4 & 9,6 & bp \\
\hline
\end{tabular}

Tabela 3. Wpływ skażeń fazą stałą i solami metali dwuwartościowych oraz temperatury na właściwości płuczek z dodatkiem OL2024

Table 3. The influence of temperature, solid phase and divalent metal salts contamination on the properties of the muds containing OL2024

\begin{tabular}{|c|c|c|c|c|c|c|c|c|c|c|c|}
\hline \multirow{3}{*}{$\begin{array}{c}\mathrm{Nr} \\
\text { płuczki }\end{array}$} & \multirow{3}{*}{\multicolumn{2}{|c|}{$\begin{array}{c}\text { Skład płuczki } \\
{[\%]}\end{array}$}} & \multirow{3}{*}{$\begin{array}{c}\text { Gęstość } \\
\rho \\
{\left[\mathrm{kg} / \mathrm{m}^{3}\right]}\end{array}$} & \multicolumn{2}{|c|}{ Lepkość } & \multirow{3}{*}{$\begin{array}{c}\text { Granica } \\
\text { płynięcia } \\
\tau y\end{array}$} & \multicolumn{2}{|c|}{$\begin{array}{l}\text { Wytrzymałość } \\
\text { strukturalna }\end{array}$} & \multirow{3}{*}{$\begin{array}{c}\text { Filtracja } \\
{\left[\mathrm{cm}^{3}\right]}\end{array}$} & \multirow{3}{*}{ pH } & \multirow{3}{*}{$\begin{array}{c}\text { Zawartość } \\
\text { poliglikolu }\end{array}$} \\
\hline & & & & $\eta p l$ & $\eta s$ & & I & II & & & \\
\hline & & & & \multicolumn{2}{|c|}{$[\mathrm{mPa} \cdot \mathrm{s}]$} & & \multicolumn{2}{|c|}{$[\mathrm{Pa}]$} & & & \\
\hline 1 & $\begin{array}{l}\text { Biocyd } \\
\text { Skrobia kleikowana } \\
\text { Biopolimer } \\
\text { KCl } \\
\text { Blokator węglanowy } \\
\text { OL2024 }\end{array}$ & $\begin{array}{c}0,1 \\
3 \\
0,3 \\
7 \\
7 \\
4\end{array}$ & 1070 & 20 & 33 & 12,5 & 2,4 & 4,6 & 14,4 & 9,3 & 3,60 \\
\hline 2 & $\begin{array}{l}\text { Płuczka } 1 \\
+ \text { zwierciny } \\
+\mathrm{NaOH}\end{array}$ & 10 & 1130 & 24 & 39 & 14,4 & 3,2 & 6,2 & 2,4 & 9,2 & 2,49 \\
\hline 3 & $\begin{array}{l}\text { Płuczka } 2 \\
+ \text { OL2024 }\end{array}$ & 1 & 1130 & 19 & 30 & 10,5 & 1,6 & 3,9 & 2,2 & 9,0 & 3,98 \\
\hline 4 & $\begin{array}{l}\text { Płuczka } 3 \\
+\mathrm{CaCl}_{2} \\
+\mathrm{NaOH}\end{array}$ & 4 & 1140 & 21 & 30 & 8,6 & 1,3 & 3,6 & 1,6 & 9,1 & $\mathrm{bp}$ \\
\hline
\end{tabular}


cd. Tabela 3 / ect. Table 3

\begin{tabular}{|c|c|c|c|c|c|c|c|c|c|c|c|}
\hline \multirow{3}{*}{$\begin{array}{c}\mathrm{Nr} \\
\text { pluczki }\end{array}$} & \multirow{3}{*}{\multicolumn{2}{|c|}{$\begin{array}{c}\text { Skład płuczki } \\
{[\%]}\end{array}$}} & \multirow{3}{*}{$\begin{array}{c}\text { Gęstość } \\
\rho \\
{\left[\mathrm{kg} / \mathrm{m}^{3}\right]}\end{array}$} & \multicolumn{2}{|c|}{ Lepkość } & \multirow{3}{*}{$\begin{array}{c}\text { Granica } \\
\text { płynięcia } \\
\tau y\end{array}$} & \multicolumn{2}{|c|}{$\begin{array}{l}\text { Wytrzymałość } \\
\text { strukturalna }\end{array}$} & \multirow{3}{*}{$\begin{array}{c}\text { Filtracja } \\
{\left[\mathrm{cm}^{3}\right]}\end{array}$} & \multirow{3}{*}{ pH } & \multirow{3}{*}{$\begin{array}{c}\text { Zawartość } \\
\text { poliglikolu }\end{array}$} \\
\hline & & & & $\eta p l$ & $\eta s$ & & I & II & & & \\
\hline & & & & \multicolumn{2}{|c|}{$[\mathrm{mPa} \cdot \mathrm{s}]$} & & \multicolumn{2}{|c|}{ [Pa] } & & & \\
\hline 5 & $\begin{array}{l}\text { Płuczka } 4 \\
+\mathrm{MgCl}_{2} \\
+\mathrm{NaOH}\end{array}$ & 1 & 1140 & 22 & 31,5 & 9,1 & 1,3 & 3,3 & 0,8 & 9,2 & bp \\
\hline 6 & $\begin{array}{l}\text { Płuczka } 5 \\
\text { Wygrzewanie temp. } 120^{\circ} \mathrm{C} \\
+\mathrm{NaOH}\end{array}$ & & 1140 & 18 & 24,5 & 6,2 & 0,9 & 1,8 & 2,4 & 9,3 & $\mathrm{bp}$ \\
\hline 7 & $\begin{array}{l}\text { Płuczka } 6 \\
+ \text { skrobia kleikowana } \\
\text { + biopolimer }\end{array}$ & $\begin{array}{l}1,5 \\
0,1\end{array}$ & 1140 & 34 & 48,5 & 13,9 & 2,6 & 6,4 & 1,6 & 9,4 & $\mathrm{bp}$ \\
\hline
\end{tabular}

Tabela 4. Wpływ skażeń fazą stałą i solami metali dwuwartościowych oraz temperatury na właściwości płuczek z dodatkiem OL2024 i emulgatora

Table 4. The influence of temperature, solid phase and divalent metal salts contamination on the properties of the muds containing OL2024 and emulsifier

\begin{tabular}{|c|c|c|c|c|c|c|c|c|c|c|c|}
\hline \multirow{3}{*}{$\begin{array}{c}\mathrm{Nr} \\
\text { pluczki }\end{array}$} & \multirow{3}{*}{\multicolumn{2}{|c|}{$\begin{array}{c}\text { Skład płuczki } \\
{[\%]}\end{array}$}} & \multirow{3}{*}{$\begin{array}{c}\text { Gęstość } \\
\boldsymbol{\rho} \\
{\left[\mathrm{kg} / \mathrm{m}^{3}\right]}\end{array}$} & \multicolumn{2}{|c|}{ Lepkość } & \multirow{3}{*}{$\begin{array}{c}\text { Granica } \\
\text { płynięcia } \\
\tau y\end{array}$} & \multicolumn{2}{|c|}{$\begin{array}{l}\text { Wytrzymałość } \\
\text { strukturalna }\end{array}$} & \multirow{2}{*}{ Filtracja } & \multirow{3}{*}{ pH } & \multirow{3}{*}{$\begin{array}{c}\text { Zawartość } \\
\text { poliglikolu }\end{array}$} \\
\hline & & & & $\eta p l$ & $\eta s$ & & I & II & & & \\
\hline & & & & \multicolumn{2}{|c|}{$[\mathrm{mPa} \cdot \mathrm{s}]$} & & \multicolumn{2}{|c|}{ [Pa] } & {$\left[\mathrm{cm}^{3}\right]$} & & \\
\hline 1 & $\begin{array}{l}\text { Biocyd } \\
\text { Skrobia kleikowana } \\
\text { Biopolimer } \\
\text { KCl } \\
\text { Blokator węglanowy } \\
\text { OL2024 } \\
\text { emulgator }\end{array}$ & $\begin{array}{c}0,1 \\
3 \\
0,3 \\
7 \\
7 \\
3 \\
1\end{array}$ & 1070 & 22 & 39,5 & 16,8 & 3,5 & 5,4 & 11,6 & 9,4 & 3,36 \\
\hline 2 & $\begin{array}{l}\text { Płuczka } 1 \\
+ \text { zwierciny } \\
+\mathrm{NaOH}\end{array}$ & 10 & 1130 & 23 & 39 & 15,3 & 3,4 & 7,3 & 2,4 & 9,3 & 1,98 \\
\hline 3 & $\begin{array}{l}\text { Płuczka } 2 \\
+ \text { OL2024 } \\
+ \text { emulgator }\end{array}$ & $\begin{array}{l}1,5 \\
0,5\end{array}$ & 1130 & 20 & 29,5 & 9,1 & 1,8 & 3,8 & 0,8 & 8,9 & 3,93 \\
\hline 4 & $\begin{array}{l}\text { Płuczka } 3 \\
+\mathrm{CaCl}_{2} \\
+\mathrm{NaOH}\end{array}$ & 4 & 1140 & 20 & 29 & 8,6 & 1,6 & 3,5 & 0,8 & 9,1 & $\mathrm{bp}$ \\
\hline 5 & $\begin{array}{l}\text { Płuczka } 4 \\
+\mathrm{MgCl}_{2} \\
+\mathrm{NaOH}\end{array}$ & 1 & 1140 & 21 & 29,5 & 8,1 & 1,5 & 3,4 & 1,6 & 9,2 & $\mathrm{bp}$ \\
\hline 6 & $\begin{array}{l}\text { Płuczka } 5 \\
\text { Wygrzewanie temp. } 120^{\circ} \mathrm{C} \\
+\mathrm{NaOH}\end{array}$ & & 1140 & 18 & 26,5 & 8,1 & 1,6 & 2,6 & 2,0 & 9,2 & $\mathrm{bp}$ \\
\hline 7 & $\begin{array}{l}\text { Płuczka } 6 \\
+ \text { skrobia kleikowana } \\
+ \text { biopolimer }\end{array}$ & $\begin{array}{l}1,5 \\
0,1\end{array}$ & 1140 & 33 & 49,5 & 15,8 & 3,0 & 9,1 & 1,6 & 9,5 & $\mathrm{bp}$ \\
\hline
\end{tabular}

poliglikolu do założonej ilości 4\% i wykonano dalsze badania. Po wygrzewaniu w autoklawach we wszystkich badanych płuczkach nastąpiło obniżenie parametrów reologicznych i podwyższenie filtracji, chociaż nie było ono znaczące. Następnie wszystkie płuczki obrobiono dodatkiem 1,5\% skrobi kleikowanej i 0,1\% biopolimeru. Obróbka za pomocą środka skrobiowego i biopolimeru powodowała przywrócenie parametrów reologicznych do odpowiedniego poziomu. Zmiany stężenia poliglikoli, parametrów reologicznych i filtracji w czasie wprowadzania skażeń oraz obróbki płuczki przedstawiono dodatkowo w formie graficznej na rysunkach 1-3. 


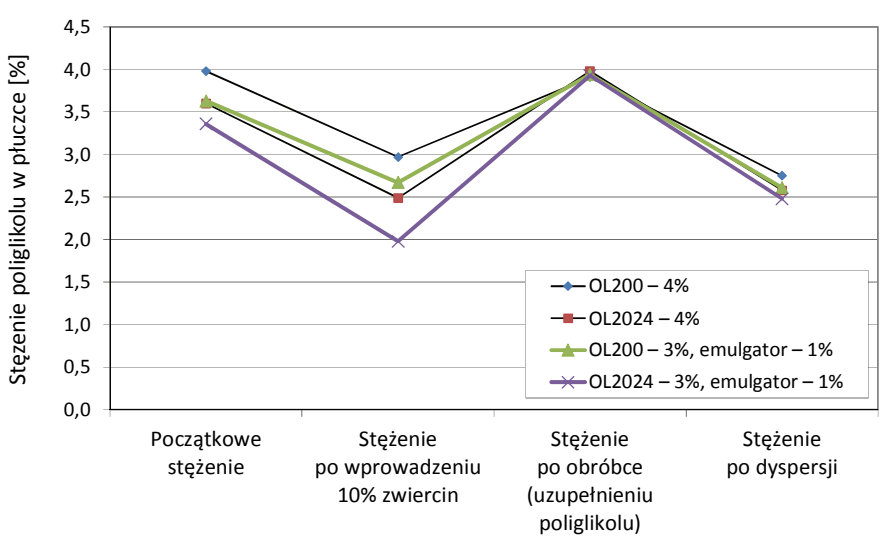

Rys. 1. Zmiany stężeń poliglikoli w płuczkach podczas wprowadzania zwiercin oraz obróbki płuczki

Fig. 1. Polyglycol concentration changes in the muds during the addition of cuttings and mud treatment
Podczas skażania i obróbki płuczek wykonano dodatkowo badania dyspersji łupku mioceńskiego w środowisku płuczek zawierających 10\% zwiercin, w których uzupełniono zawartość poliglikolu do 4\% (rys. 5). Uzyskane wartości odzysku skały dla płuczek zawierających zwierciny są na podobnym poziomie jak płuczek nieskażonych lub nieznacznie wyższe. Potwierdza to, że w czasie wiercenia kontrolowanie stężenia poliglikolu zapewnia utrzymanie inhibitacyjnych właściwości płuczek na odpowiednim poziomie.

We wszystkich płuczkach obserwowano wzrost parametrów reologicznych i znaczne obniżenie filtracji po wprowadzeniu zwiercin. Parametry reologiczne płuczek były stabilne po wprowadzaniu skażeń w postaci soli metali dwuwartościowych i nie obserwowano większych zmian w filtracji płuczek zarówno po skażeniu, jak i wygrzewaniu w autoklawach.

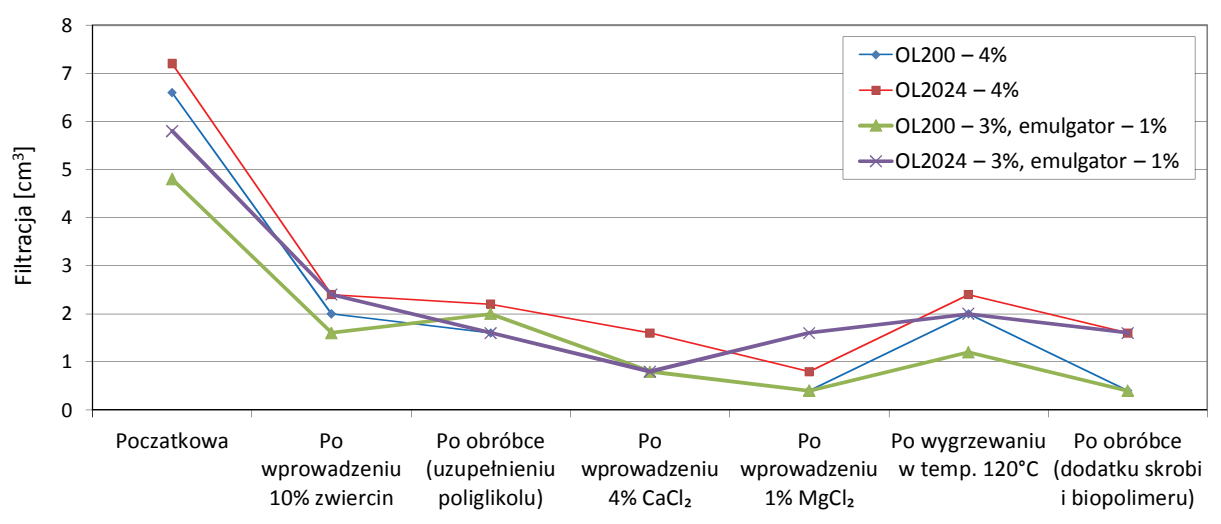

Rys. 2. Zmiany filtracji w czasie wprowadzania skażeń oraz obróbki płuczki

Fig. 2. Filtration changes of the muds during the addition of contaminations and mud treatment

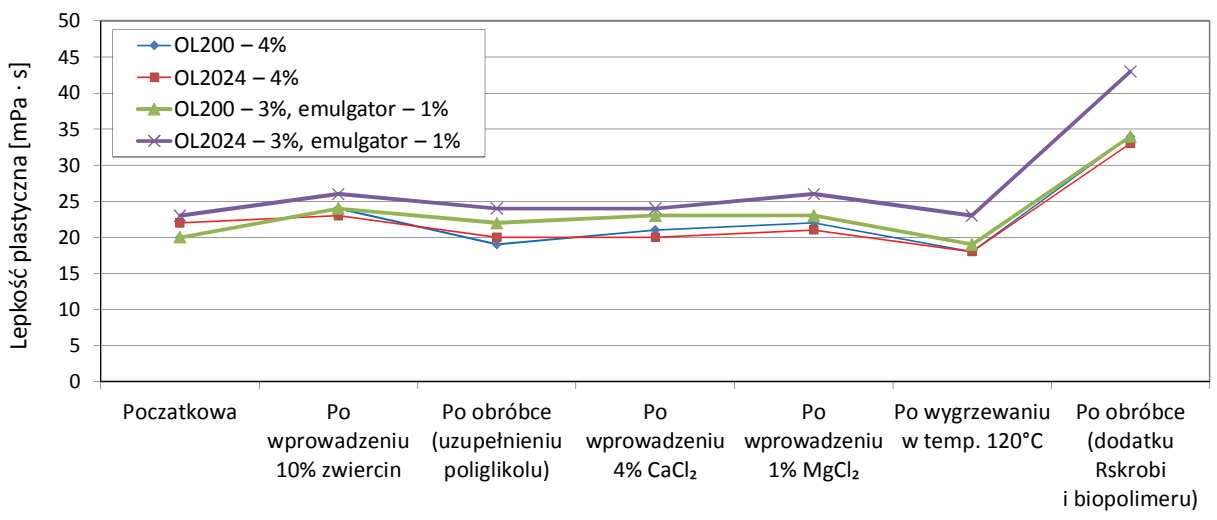

Rys. 3. Zmiany lepkości plastycznej w czasie wprowadzania skażeń oraz obróbki płuczki

Fig. 3. Plastic viscosity changes of the muds during the addition of contaminations and mud treatment

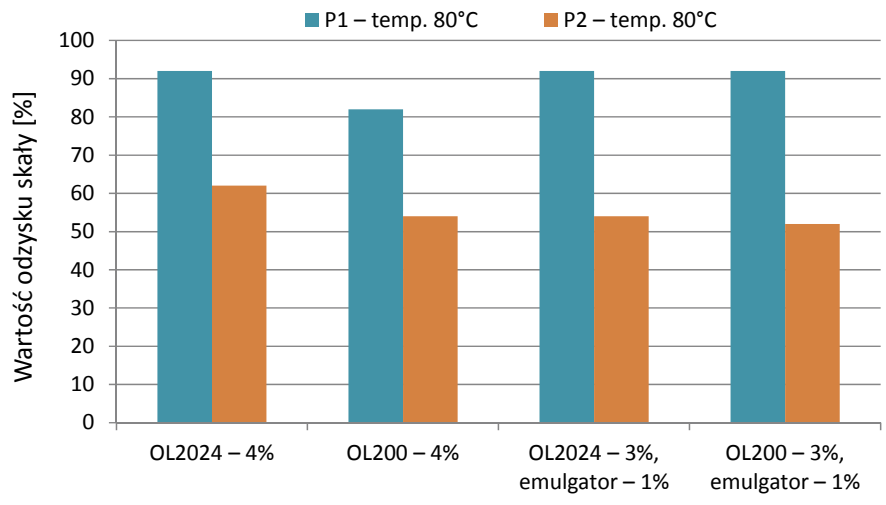

Rys. 4. Wyniki analizy dyspersyjnej łupku mioceńskiego w środowisku płuczek zawierających różne poliole w temperaturze $80^{\circ} \mathrm{C}$; $\mathrm{P}_{1}$ - odzysk łupka po dyspergowaniu w płuczce, $\mathrm{P}_{2}$ - odzysk łupka po dyspergowaniu w wodzie

Fig. 4. Results of Miocene shale dispersion analysis in the muds containing various polyols at a temperature of $80^{\circ} \mathrm{C} ; \mathrm{P}_{1}-$ shale recovery after dispersion in mud, $\mathrm{P}_{2}-$ shale recovery after dispersion in water 


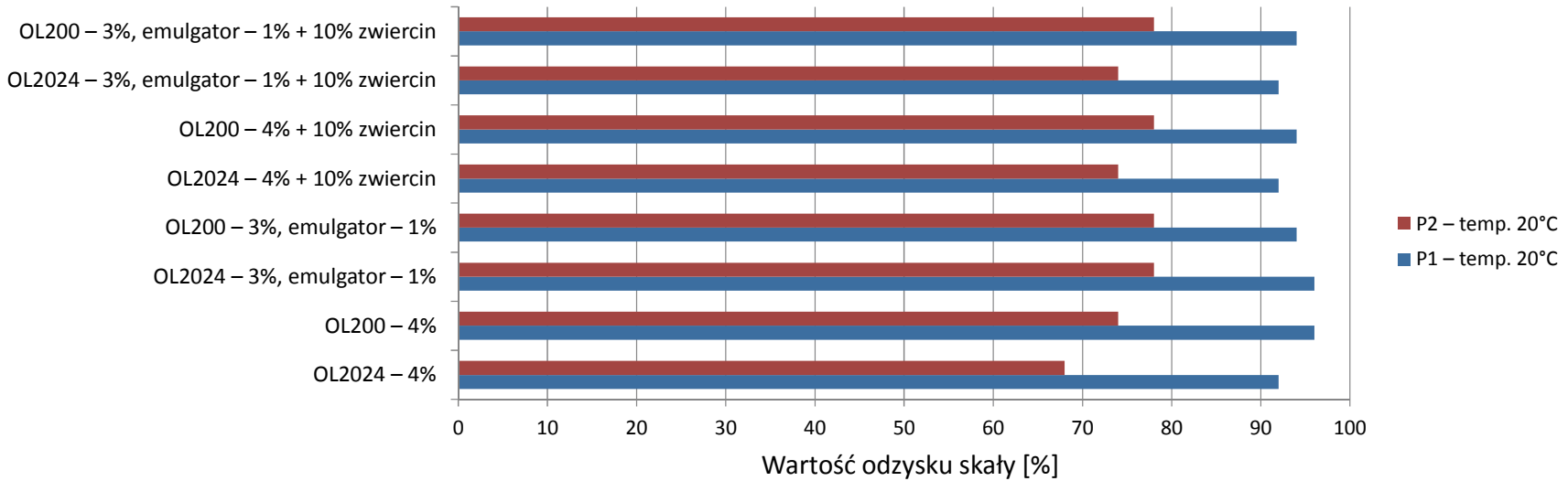

Rys. 5. Porównanie wyników analizy dyspersyjnej łupku mioceńskiego w środowisku płuczek zawierających różne poliglikole z dodatkiem i bez dodatku zwiercin w temperaturze $20^{\circ} \mathrm{C}$; $\mathrm{P}_{1}$ - odzysk łupka po dyspergowaniu w płuczce, $\mathrm{P}_{2}$ - odzysk łupka po dyspergowaniu w wodzie.

Fig. 5. Comparison of the results of the Miocene shale dispersion analysis in the muds containing various polyglycols, with and without the addition of cuttings at temperature $20^{\circ} \mathrm{C} ; \mathrm{P}_{1}$ - shale recovery after dispersion in mud, $\mathrm{P}_{2}-$ shale recovery after dispersion in water

Wartości filtracji płuczek wyjściowych (nieskażanych) były dość wysokie, najniższe wartości filtracji posiadały płuczki zawierające po $4 \%$ OL2024.

Wyniki analizy dyspersyjnej tupku mioceńskiego w temperaturze $80^{\circ} \mathrm{C}$ (rys. 4) potwierdzają wysoki stopień inhibitacji hydratacji skał dla wszystkich badanych płuczek zawierających poliole. Odzyski łupku, po płuczce osiągają wartości bliskie $100 \%\left(\mathrm{P}_{1}=90-100 \%\right)$, w temperaturze $20^{\circ} \mathrm{C}$. Wartości $\mathrm{P}_{2}$ płuczek wynoszą 65-75\%, przy czym najbardziej efektywnymi środkami były OL2024 i OL200 z dodatkiem emulgatora. $\mathrm{W}$ temperaturach wyższych dodatek emulgatora nie wpływa już tak korzystnie na wartości dyspersji. W temperaturze $80^{\circ} \mathrm{C}$ najbardziej efektywnym jest środek OL2024 bez dodatku emulgatora. Wysoką efektywność w tej temperaturze wykazuje również OL200.

Pomiary pęcznienia skały ilastej (łupku mioceńskiego) w środowisku badanych płuczek wskazują, że najskuteczniejszym inhibitorem zabezpieczającym skały przed pęcznieniem jest OL2024 zarówno z dodatkiem, jak i bez dodatku emulgatora (rys. 6).

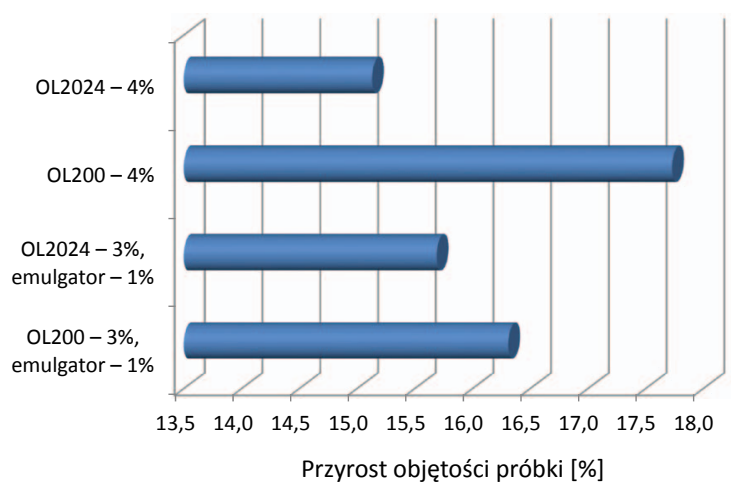

Rys. 6. Wyniki pomiarów pęcznienia [\%] łupku mioceńskiego w środowisku płuczek zawierających różne poliole

Fig. 6. Results of swelling measurements [\%] of the Miocene shale in the muds containing various polyols.

\section{Badania płuczek $z$ dodatkiem pochodnych alkoholi tłuszczowych w warunkach otworopodobnych}

Badania zmian parametrów reologicznych płuczek pod wpływem temperatury przeprowadzone za pomocą wiskozymetru OfiTE 77 (rys. 7-22) potwierdziły ich stabilność w zakresie $20-120^{\circ} \mathrm{C}$. Cały cykl badawczy trwał $3-4$ godz., natomiast płuczka w temperaturze zbliżonej do $120^{\circ} \mathrm{C}$ przebywała

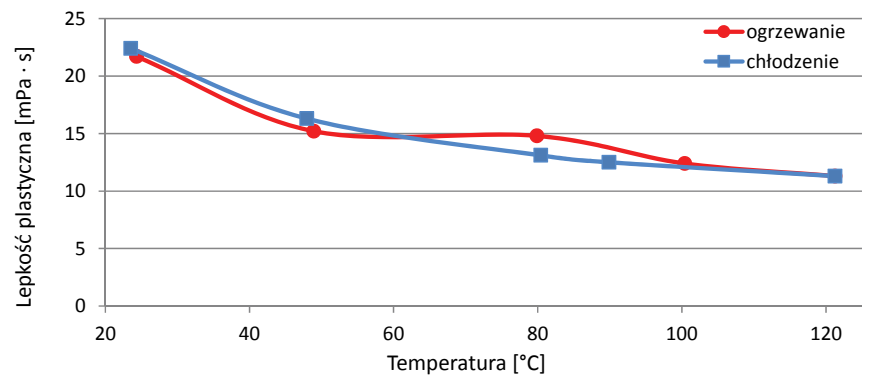

Rys. 7. Wykres zmian lepkości plastycznej płuczki z dodatkiem $4 \%$ OL200 od temperatury w zakresie $20-120^{\circ} \mathrm{C}$

Fig. 7. Plastic viscosity changes in the mud containing 4\% OL200 versus the temperature in the range $20-120^{\circ} \mathrm{C}$ plot

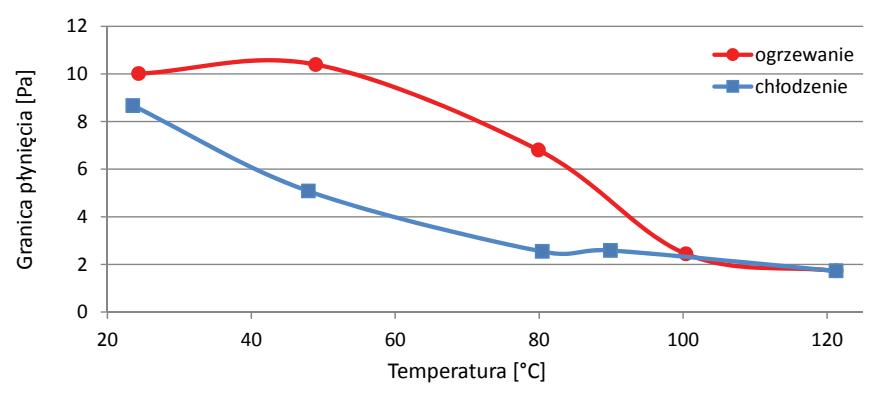

Rys. 8. Wykres zmian granicy płynięcia płuczki z dodatkiem 4\% OL200 od temperatury w zakresie $20-120^{\circ} \mathrm{C}$

Fig. 8. Yield point changes in the mud containing 4\% OL200 versus the temperature in the range $20-120^{\circ} \mathrm{C}$ plot 


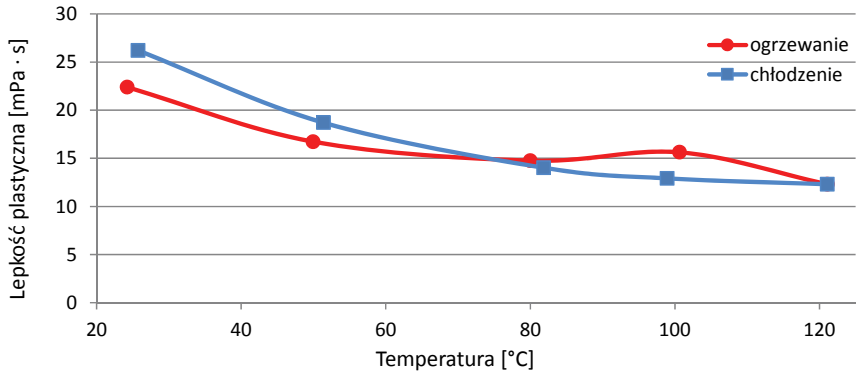

Rys. 9. Wykres zmian lepkości plastycznej płuczki z dodatkiem 3\% OL 200 i $1 \%$ emulgatora od temperatury w zakresie $20-120^{\circ} \mathrm{C}$

Fig. 9. Plastic viscosity changes in the mud containing 3\% OL200 and $1 \%$ emulsifier versus the temperature in the range $20-120^{\circ} \mathrm{C}$ plot

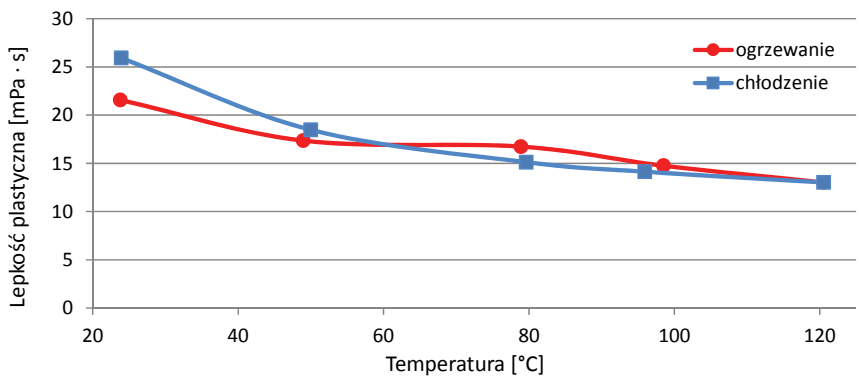

Rys. 11. Wykres zmian lepkości plastycznej płuczki z dodatkiem $4 \%$ OL2024 od temperatury w zakresie $20-120^{\circ} \mathrm{C}$

Fig. 11. Plastic viscosity changes in the mud containing $4 \%$ OL2024 versus the temperature in the range $20-120^{\circ} \mathrm{C}$ plot

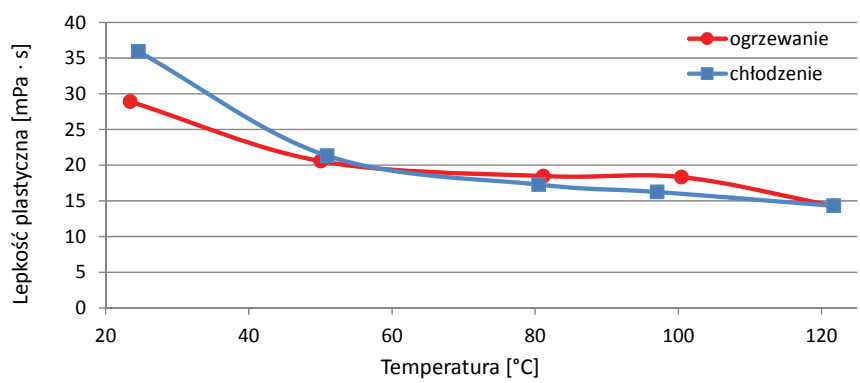

Rys. 13. Wykres zmian lepkości plastycznej płuczki z dodatkiem $3 \%$ OL2024 i $1 \%$ emulgatora od temperatury w zakresie $20-120^{\circ} \mathrm{C}$

Fig. 13. Plastic viscosity changes in the mud containing 3\% OL2024 and $1 \%$ emulsifier versus the temperature in the range $20-120^{\circ} \mathrm{C}$ plot

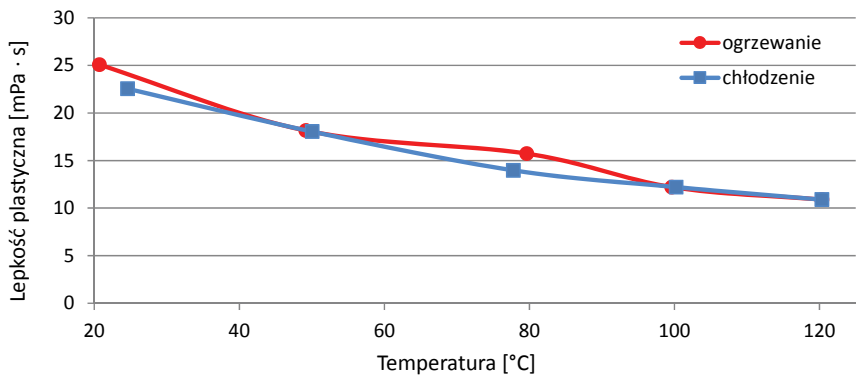

Rys. 15. Wykres zmian lepkości plastycznej płuczki z dodatkiem $4 \%$ OL200 skażonej $10 \%$ zwiercin oraz $4 \% \mathrm{CaCl}_{2}$ i $1 \% \mathrm{MgCl}_{2}$ od temperatury w zakresie $20-120^{\circ} \mathrm{C}$

Fig. 15. Plastic viscosity changes in the mud containing $4 \%$ OL200, $10 \%$ cuttings, $4 \% \mathrm{CaCl}_{2}$ and $1 \% \mathrm{MgCl}_{2}$ versus the temperature in the range $20-120^{\circ} \mathrm{C}$ plot

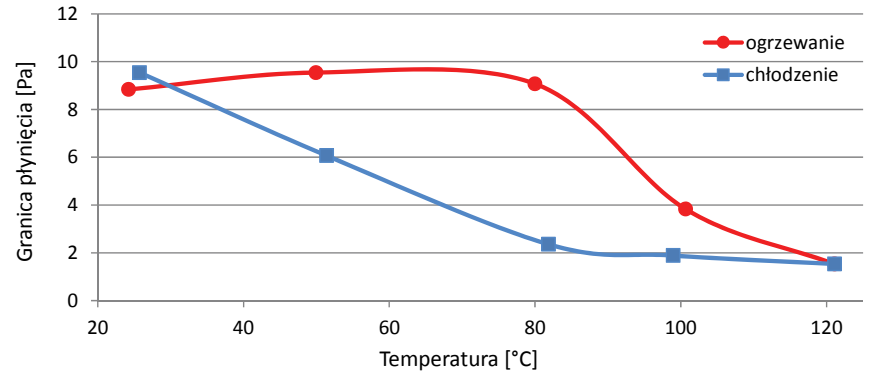

Rys. 10. Wykres zmian granicy płynięcia płuczki z dodatkiem 3\% OL 200 i $1 \%$ emulgatora od temperatury w zakresie $20-120^{\circ} \mathrm{C}$

Fig. 10. Yield point changes in the mud containing 3\% OL200 and $1 \%$ emulsifier versus the temperature in the range $20-120^{\circ} \mathrm{C}$ plot

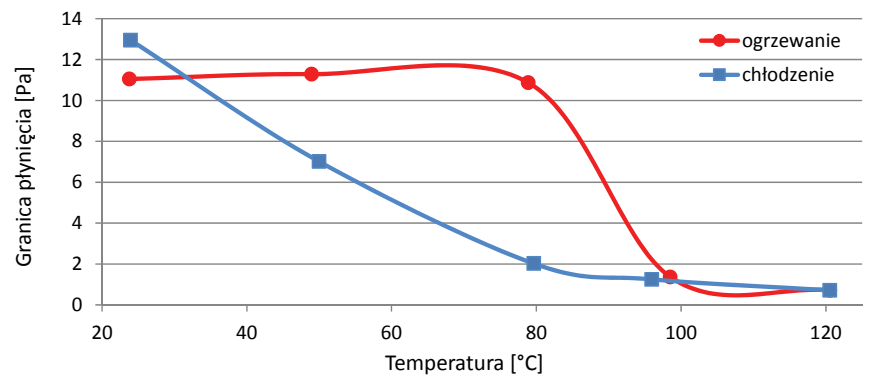

Rys. 12. Wykres zmian granicy płynięcia płuczki z dodatkiem $4 \%$ OL2024 od temperatury w zakresie $20-120^{\circ} \mathrm{C}$

Fig. 12. Yield point changes in the mud containing 4\% OL2024 versus the temperature in the range $20-120^{\circ} \mathrm{C}$ plot

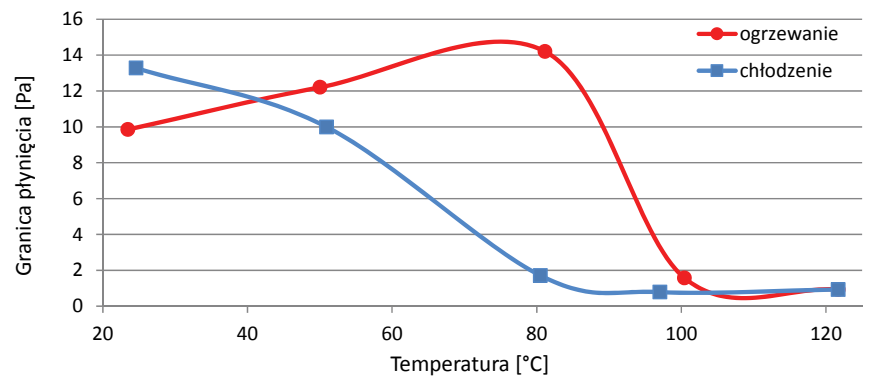

Rys. 14. Wykres zmian granicy płynięcia płuczki z dodatkiem 3\% OL2024 i $1 \%$ emulgatora od temperatury w zakresie $20-120^{\circ} \mathrm{C}$

Fig. 14. Yield point changes in the mud containing 3\% OL2024 and $1 \%$ emulsifier versus the temperature in the range $20-120^{\circ} \mathrm{C}$ plot

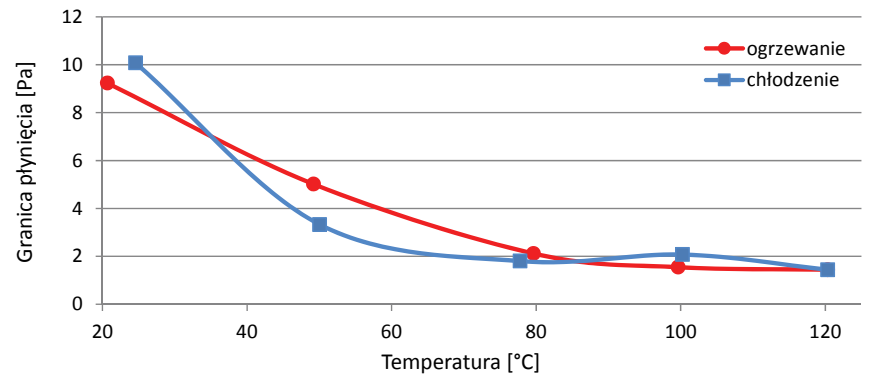

Rys. 16. Wykres zmian granicy płynięcia płuczki z dodatkiem $4 \%$ OL200 skażonej $10 \%$ zwiercin oraz $4 \% \mathrm{CaCl}_{2}$ i $1 \% \mathrm{MgCl}_{2}$ od temperatury w zakresie $20-120^{\circ} \mathrm{C}$

Fig. 16. Yield point changes in the mud containing 4\% OL200, $10 \%$ cuttings, $4 \% \mathrm{CaCl}_{2}$ and $1 \% \mathrm{MgCl}_{2}$ versus the temperature in the range $20-120^{\circ} \mathrm{C}$ plot 


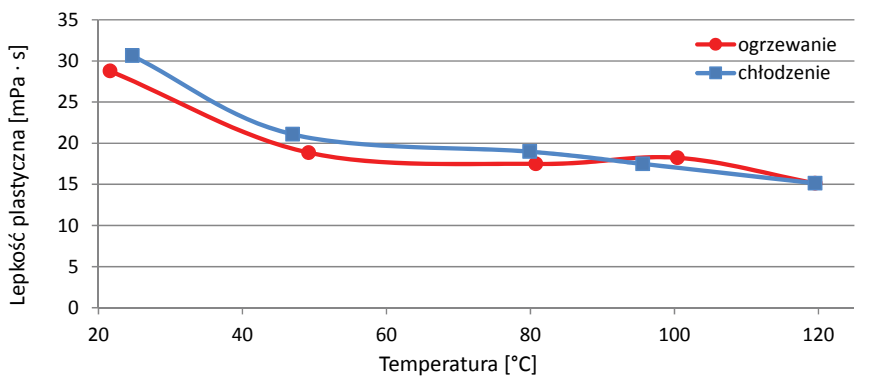

Rys. 17. Wykres zmian lepkości plastycznej płuczki z dodatkiem 3\% OL200 i 1\% emulgatora skażonej 10\% zwiercin oraz 4\% $\mathrm{CaCl}_{2}$ i $1 \% \mathrm{MgCl}_{2}$ od temperatury w zakresie $20-120^{\circ} \mathrm{C}$

Fig. 17. Plastic viscosity changes in the mud containing $3 \%$ OL200, $1 \%$ emulsifier, $10 \%$ cuttings, $4 \% \mathrm{CaCl}_{2}$ and $1 \% \mathrm{MgCl}_{2}$ versus the temperature in the range $20-120^{\circ} \mathrm{C}$ plot

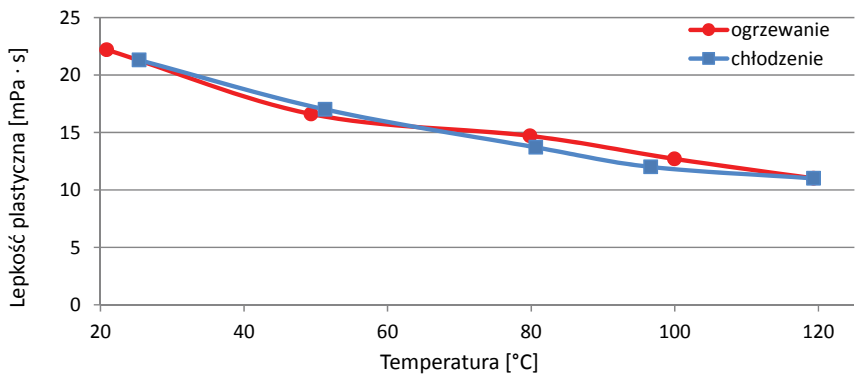

Rys. 19. Wykres zmian lepkości plastycznej płuczki z dodatkiem $4 \%$ OL2024 skażonej $10 \%$ zwiercin oraz $4 \% \mathrm{CaCl}_{2}$ i $1 \% \mathrm{MgCl}_{2}$ od temperatury w zakresie $20-120^{\circ} \mathrm{C}$

Fig. 19. Plastic viscosity changes in the mud containing $4 \%$ OL2024, $10 \%$ cuttings, $4 \% \mathrm{CaCl}_{2}$ and $1 \% \mathrm{MgCl}_{2}$ versus the temperature in the range $20-120^{\circ} \mathrm{C}$ plot

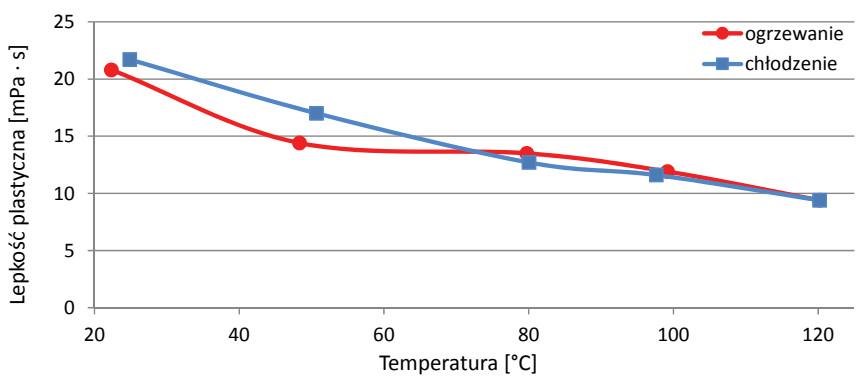

Rys. 21. Wykres zmian lepkości plastycznej płuczki z dodatkiem $3 \%$ OL2024 i 1\% emulgatora skażonej 10\% zwiercin oraz 4\% $\mathrm{CaCl}_{2}$ i $1 \% \mathrm{MgCl}_{2}$ od temperatury w zakresie $20-120^{\circ} \mathrm{C}$

Fig. 21. Plastic viscosity changes in the mud containing $3 \%$ OL2024, $1 \%$ emulsifier, $10 \%$ cuttings, $4 \% \mathrm{CaCl}_{2}$ and $1 \% \mathrm{MgCl}_{2}$ versus the temperature in the range $20-120^{\circ} \mathrm{C}$ plot

około 20 min. W tak krótkim czasie nie nastąpił rozkład polimerów, w związku z tym po ochłodzeniu parametry reologiczne wszystkich płuczek nie ulegały znaczącemu obniżeniu w stosunku do wartości wyjściowych. Obserwowano natomiast różnice w przebiegach krzywych dla ogrzewania i ochładzania płuczek. Nie zaobserwowano również różnic w stabilności termicznej płuczek zawierających dodatki różnych polioli.

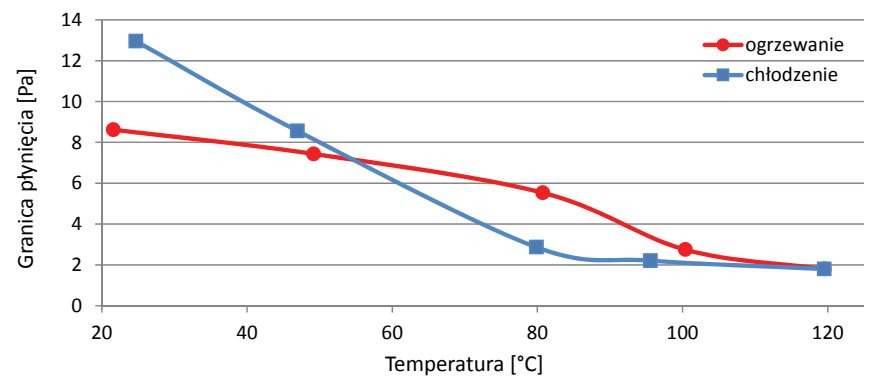

Rys. 18. Wykres zmian granicy płynięcia płuczki z dodatkiem 3\% OL200 i 1\% emulgatora skażonej $10 \%$ zwiercin oraz $4 \% \mathrm{CaCl}_{2}$ i $1 \% \mathrm{MgCl}_{2}$ od temperatury w zakresie $20-120^{\circ} \mathrm{C}$

Fig. 18. Yield point changes in the mud containing 3\% OL200, $1 \%$ emulsifier, $10 \%$ cuttings, $4 \% \mathrm{CaCl}_{2}$ and $1 \% \mathrm{MgCl}_{2}$ versus the temperature in the range $20-120^{\circ} \mathrm{C}$ plot

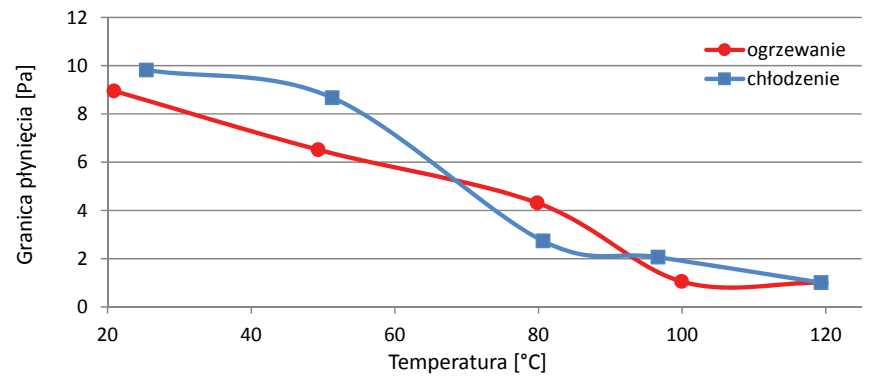

Rys. 20. Wykres zmian granicy płynięcia płuczki z dodatkiem $4 \%$ OL2024 skażonej $10 \%$ zwiercin oraz $4 \% \mathrm{CaCl}_{2}$ i $1 \% \mathrm{MgCl}_{2}$ od temperatury w zakresie $20-120^{\circ} \mathrm{C}$

Fig. 20. Yield point changes in the mud containing 4\% OL2024, $10 \%$ cuttings, $4 \% \mathrm{CaCl}_{2}$ and $1 \% \mathrm{MgCl}_{2}$ versus the temperature in the range $20-120^{\circ} \mathrm{C}$ plot

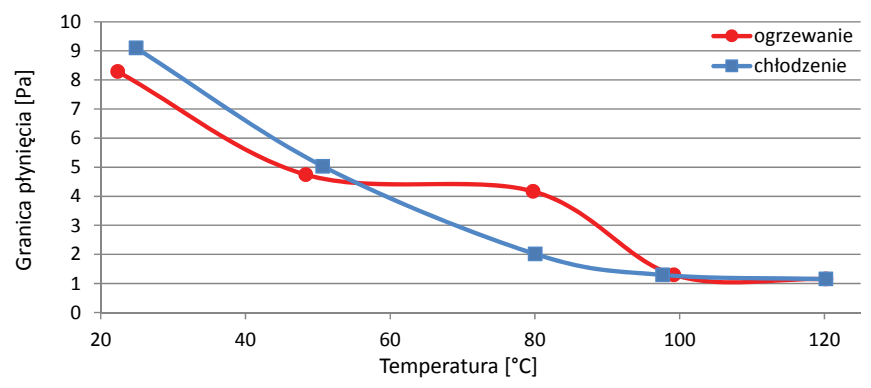

Rys. 22. Wykres zmian granicy płynięcia płuczki z dodatkiem 3\% OL2024 i 1\% emulgatora skażonej $10 \%$ zwiercin oraz $4 \% \mathrm{CaCl}_{2}$ i $1 \% \mathrm{MgCl}_{2}$ od temperatury w zakresie $20-120^{\circ} \mathrm{C}$

Fig. 22. Yield point changes in the mud containing 3\% OL2024, $1 \%$ emulsifier, $10 \%$ cuttings, $4 \% \mathrm{CaCl}_{2}$ and $1 \% \mathrm{MgCl}_{2}$ versus the temperature in the range $20-120^{\circ} \mathrm{C}$ plot

Dla wybranych płuczek, sporządzonych na osnowie koloidu skrobiowego i biopolimeru z 4\%-owym dodatkiem polioli przeprowadzono badania statycznej filtracji HPHT (rys. 23). Najniższe wartości filtracji uzyskano dla płuczek z dodatkiem emulgatora, który korzystnie wpływa na obniżenie filtracji zarówno w połączeniu z OL200, jak i OL2024. W badaniach filtracji w podwyższonej temperaturze 50 i $120^{\circ} \mathrm{C}$ uzyskano 
podobne zależności, jak w przypadku filtracji API w temperaturze otoczenia - jedynie ich wartości były odpowiednio wyższe. Wartość filtracji płuczki z dodatkiem 3\% OL200 i 1\% emulgatora wynosiła w temperaturze $120^{\circ} \mathrm{C}$ około $11 \mathrm{~cm}^{3}$, a najwyższa filtracja $\mathrm{w}$ tej temperaturze dla płuczki z dodatkiem $4 \%$ OL2024 wynosiła około $13 \mathrm{~cm}^{3}$.

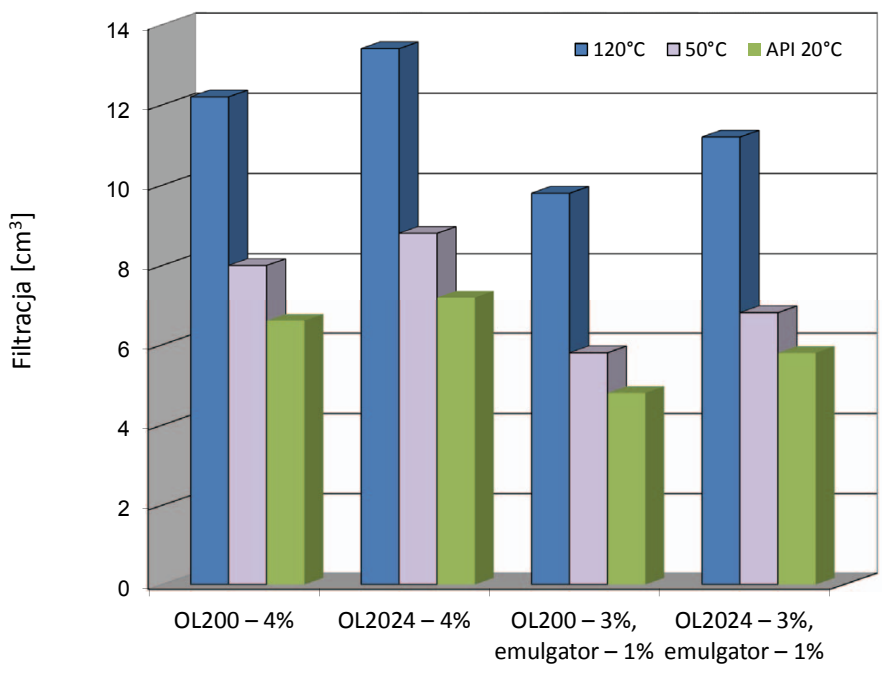

Rys. 23. Wartość filtracji API i HPHT płuczek na osnowie skrobi kleikowanej i biopolimeru z 4\%-owym dodatkiem różnych polioli

Fig. 23. API and HPHT filtration of the muds containing starch, biopolymer and $4 \%$ of various polyols

\section{Określenie wpływu opracowanych płuczek na uszkodzenie przepuszczalności wzorcowej skały zbiornikowej}

Badania utraty przepuszczalności przeprowadzono na próbkach piaskowca szydłowieckiego. Do badań użyto 4 płuczek wiertniczych o składach opisanych wyżej (tab. 1-4, poz. 1).

Dla wstępnego nasycenia próbek użyto $5 \%$ roztworu $\mathrm{NaCl}$. Pomiar przepuszczalności efektywnej (początkowej, końcowej) przeprowadzono przy użyciu gazu (azot). Badania uszkodzenia wykonywane były w temperaturze $50^{\circ} \mathrm{C}$. Wyniki pomiarów utraty przepuszczalności wytypowanych próbek pod wpływem użytych w badaniu płuczek wiertniczych przedstawiono na rysunku 24.

Analiza wyników wskazuje, że procentowa wartość utraty przepuszczalności mieści się w przedziale od 43,33\% (płuczka z dodatkiem OL200) do 71,56\% (płuczka nr 4 z dodatkiem OL2024). Rezultaty uzyskanych wyników analiz wskazują na znaczny spadek właściwości filtracyjnych. Użyte w badaniach płuczki wpływają niekorzystnie na zachowanie pierwotnej przepuszczalności badanych skał. Otrzymane wielkości uszkodzenia przepuszczalności przekraczają poziom $20 \%$ po, co jest niepożądane z punktu widzenia prowadzenia eksploatacji.

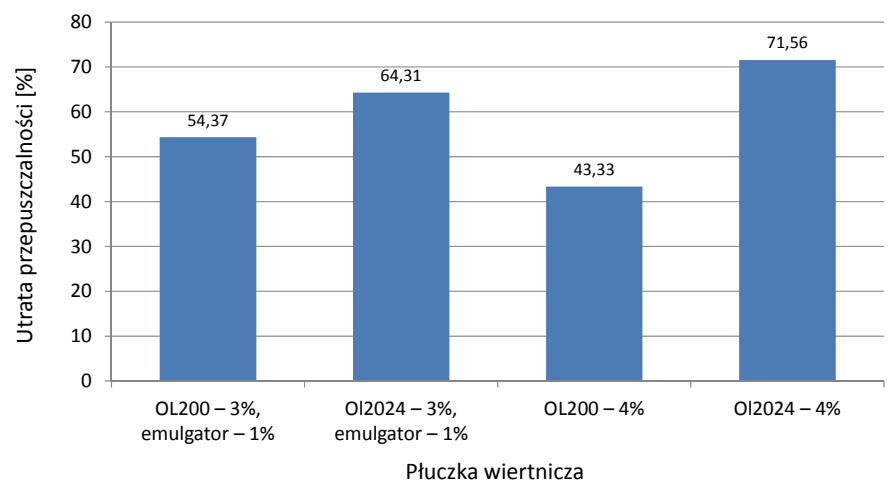

Rys. 24. Utrata przepuszczalności płuczek zawierających różne poliole

Fig. 24. Permeability damage of the muds containing various polyols

\section{Wnioski}

Uzyskane wyniki badań nowych inhibitorów hydratacji skał (OL200 i OL2024) w środowisku płuczek wiertniczych potwierdzają, że wykazują one wyższą efektywność od obecnie stosowanych poliglikoli wiertniczych. Szczególną efektywność działania w zakresie ograniczenia hydratacji skał ilastych nowoopracowane poliglikole potwierdzają w środowisku płuczek wiertniczych w temperaturach podwyższonych, tj. około $80^{\circ} \mathrm{C}$.

Optymalnym rozwiązaniem w warunkach przemysłowych jest zastosowanie jako inhibitora hydratacji skał ilastych OL2024 lub OL200, ponieważ wykazują one wysoką efektywność działania w szerokim zakresie temperatury występującym w otworze. Podczas głębienia otworu na mniejszych głębokościach, w temperaturach niższych (do $50^{\circ} \mathrm{C}$ ) wskazane jest zastosowanie do nich dodatku emulgatora w ilości 1\%. Na większych głębokościach, w temperaturach wyższych należy natomiast zaprzestać dodatku tego emulgatora. Płuczki sporządzone na osnowie koloidu skrobiowego zachowują stabilne parametry reologiczne po ogrzewaniu i następnie ochłodzeniu w zakresie temperatury $20-120^{\circ} \mathrm{C}$, co potwierdziły pomiary parametrów reologicznych wykonane za pomocą wiskozymetru OfiTE 77. W czasie ogrzewania płuczek obserwuje się podwyższone wartości granicy płynięcia w zakresie temperatury $20-80^{\circ} \mathrm{C}$, co może być spowodowane przejściowym powstawaniem emulsji o podwyższonych parametrach reologicznych. Zjawisko to nie występuje w czasie ochładzania próbki płuczki. W ramach zlecenia opracowano składy płuczek wiertniczych zawierających nowe inhibitory hydratacji skał. Przeprowadzone badania potwierdziły, że dedykowanym do tego typu płuczek koloidem ochronnym jest środek skrobiowy. W opracowanych płuczkach jako środek strukturotwórczy należy zastosować biopolimer ksantan. 
Oprócz inhibitora polimerowego - poliglikolu należy zastosować dodatek inhibitora jonowego $\mathrm{KCl}$ oraz możliwe jest zastosowanie inhibitora polimerowego typu PHPA.

Wyniki badania wpływu opracowanych płuczek na właściwości skał zbiornikowych wskazują na znaczące uszkodzenie ich przepuszczalności. Najmniejsze uszkodzenie spośród płuczek z dodatkiem nowych rodzajów poliglikoli uzyskano dla płuczki zawierającej 4\% OL200, które wynosiło ok. 34\%. W praktyce przemysłowej przyjmuje się, że uszkodzenie dla płuczek do dowiercania złóż nie powinno wynosić więcej niż 20\%. W związku z tym mimo, że płuczki te charakteryzują się dużą zdolnością ograniczania hydratacji skał ilastych, zastosowanie ich do dowiercania nie jest wskazane. Dla oznaczania zawartości poliglikoli w płuczce wykorzystano metodę ekstrakcyjną, stosowaną w warunkach laboratoryjnych i przemysłowych. Skuteczność tej metody potwierdziły uzyskane wyniki badań i może ona być stosowana również dla nowych poliglikoli. Możliwość kontrolowania stężenia nowych inhibitorów w płuczce jest warunkiem wdrożenia ich do praktyki przemysłowej.

Opracowane płuczki wykazują stabilność parametrów reologicznych i filtracji po wprowadzeniu zwiercin i skażeń chemicznych w postaci chlorków metali dwuwartościowych. Opracowane płuczki wymagały jedynie obróbki w celu uzupełnienia zawartości poliglikolu po wprowadzeniu zwiercin oraz dodatku środka skrobiowego i biopolimeru w celu regulowania parametrów reologicznych po wygrzewaniu w autoklawach przez 16 godzin w temperaturze $120^{\circ} \mathrm{C}$.

Artykuł powstał na podstawie pracy pt.: Opracowanie płuczki wiertniczej z dodatkiem pochodnych alkoholi tluszczowych dla warunków otworowych - praca statutowa INiG - PIB na zlecenie MNiSW; nr zlecenia: 0046/KW/2019, nr archiwalny: DK-4100-0036/2019.

\section{Literatura}

Akram M.W., Meyer J.L., Polycarpou A.A., 2016. Tribological interactions of advanced polymeric coatings with polyalkylene glycol lubricant and r1234yf refrigerant. Tribology International, 97: 200-211. DOI: 10.1016/j.triboint.2016.01.026.

Aston M. S., Elliot G. P., 1994. Water based glycol drilling muds: shale inhibition mechanism. Society of Petroleum Engineers. DOI: $10.2118 / 28818-M S$.

Aziz N.A.M., Raschid U., Zulkifli N.W.M., 2016. Temperature effect on tribological properties of polyol ester-based environmentally adapted lubricant. Tribology International, 93: 43-49. DOI: 10.1016/j.triboint.2015.09.014.

Balaban R.C. de, Vidal E.L.F., Borges M.R., 2015. Design of experiments to evaluate clay swelling inhibition by different combinations of organic compounds and inorganic salts for application in water base drilling fluids. Applied Clay Science, 105-106: 124-130. DOI: 10.1016/j.clay.2014.12.029.

Bielewicz D., Bortel E., 2000. Polimers in drilling fluids technology. AGH Uczelniane Wydawnictwa Naukowo-Dydaktyczne, Kraków.
Ferreira C.C., Teixeira G.T., Lachter E.R., Nascimento R.S.V., 2016. Partially hydrophobized hyperbranched polyglycerols as non-ionic reactive shale inhibitors for water-based drilling fluids. Applied Clay Science, 132-133: 122-132. DOI: 10.1016/j.clay.2016.05.025.

Gholami R., Elochukwu H., Fakhari N., Sarmadivaleh M., 2018. A review on borehole instability in active shale formations: Interactions, mechanisms and inhibitors. Earth-Science Reviews, 177: 2-13. DOI: 10.1016/j.earscirev.2017.11.002.

He S., Liang L., Zeng Y., Ding Y., Lin Y., Liu X., 2016. The influence of water-based drilling fluid on mechanical property of shale and the wellbore stability. Petroleum, 2: 61-66. DOI: 10.1016/j. petlm.2015.12.002.

Jasiński B., 2015. Comparison of the effect of inhibited drilling muds parameters on the physical and mechanical properties of shale rocks. Nafta-Gaz, 6: 418-424.

Jasiński B., 2016. The impact of wash fluids on the quality of casing cementing after using glycol based drilling mud. Nafta-Gaz, 6: 413-421, DOI: 10.18668/NG.2016.06.04.

Jasiński B., 2017. Analysis of lubricity additives effectiveness based on research performed with the Grace M2200 drilling simulator. Nafta-Gaz, 4: 257-265, DOI: 10.18668/NG.2017.04.06.

Kania D., Yunus R., Omar R., Rashid S.A., Jan B.M., Arsanjani N., 2018. Nonionic polyol esters as thinner and lubricity enhancer for synthetic-based drilling fluids. Journal of Molecular Liquids, 266: 846-855. DOI: 10.1016/j.molliq.2018.07.014.

Kazemi-Beydokhti A., Hajiabadi S.H., 2018. Rheological investigation of smart polymer/carbon nanotube complex on properties of water-based drilling fluids. Colloids and Surfaces A, 556: 23-29. DOI: 10.1016/j.colsurfa.2018.07.058.

Khodja M., Canselier J.P., Bergaya F., Fourar K., Khodia M., Cohuat N., Benmounah A., 2010. Shale problems and waterbased drilling fluid optimization in the Hassi Messaoud Algerian oil field. Applied Clay Science, 49: 383-393. DOI: 10.1016/j. clay.2010.08.008.

Kulawardana E. U., Koh, H., Kim D. H., Liyanage P. J., Upamali K., Huh C., Pope G. A., 2012. Rheology and Transport of Improved EOR Polymers under Harsh Reservoir Conditions. Society of Petroleum Engineers. DOI: 10.2118/154294-MS.

Lange P., Keilhofer G., 2004. Industrial Biopolymers for Oilwell Drilling: Xanthan Gum, Scleroglucan and how both differ at elevated temperatures. Degussa Construction Polymers GmbH, Trostberg, Germany.

Leonhardt B., Ernst B., Reimann S., Steigerwald A., Lehr F., 2014. Field Testing the Polysaccharide Schizophyllan: Results of The First Year. Society of Petroleum Engineers. DOI: 10.2118/169032-MS.

Luyster M.R., Tresco K., Dobson J., Ravitz R., Eyaa Allogo C.M., Sooi Lim K., 2016. An Assessment of an Uncomplicated Drill-in Fluid and Its Application to a Wide Range of Global Completions and Their Recent Successes. Society of Petroleum Engineers. DOI: 10.2118/179037-MS.

Ogonowski J., Tomaszkiewicz-Potępa A., 1999. Surfactants. Wydawnictwo Politechniki Krakowskiej.

Oort E. van, 2003. On the physical and chemical stability of shales. Journal of Petroleum Science and Engineering, 38: 213-235. DOI: 10.1016/S0920-4105(03)00034-2.

Oort E. van, Bland R.G., Roberson L., 1997. Improving HPHT Stability of Water Based Drilling Fliuds. SPE/IADC 37605. DOI: 10.2118/37605-MS.

Queiroz J., dos Santos R.L., 2000. Evolution of a Damaged Zone Caused by Water-Based Polymeric Drill-In Fluid. Society of Petroleum Engineers. DOI: 10.2118/58742-MS. 
Razali S.Z., Yunus R., Rashid S.A., Lim H.N., Jan B.M., 2018. Review of biodegradable synthetic-based drilling fluid: Progression, performance and future prospect. Renewable and Sustainable Energy Reviews, 90: 171-186. DOI: 10.1016/j.rser.2018.03.014.

Reid P.I., Dolan B., Cliffe S., 1995. Mechanism of Shale Inhibition by Polyols in Water Based Drilling Fluids. Society of Petroleum Engineers. DOI: 10.2118/28960-MS.

Samaei S.M., Tahmasbi K., 2007. The possibility of replacing oilbased mud with the environmentally acceptable water based glycol based drilling mud for the Iranian fields. Society of Petroleum Engineers. DOI: 10.2118/106419-MS.

Sayindla S., Lund B., Ytrehus J.D., Saasen A., 2017. Hole-cleaning performance comparison of oil-based and water-based drilling fluids. Journal of Petroleum Science and Engineering, 159: 49-57. DOI: $10.1016 /$ j.petrol.2017.08.069.

Taugbol K., Svanes G., Svanes K., Omland T.H., Alteraas E., Mathisen A.M., 2005. Investigation of Flow-Back Properties of Various Drilling and Completion Fluids through Production Screens. Society of Petroleum Engineers. DOI: 10.2118/94558-MS.

Villabona-Estupinan S., Rodrigues J. de A., Nascimento R.S.V., 2017. Understanding the clay-PEG (and hydrophobic derivatives) interactions and their effect on clay hydration and dispersion: A comparative study. Applied Clay Science, 143: 89-100. DOI: 10.1016/j.clay.2017.03.021.

Xiao H., Liu S., Chen Y., Han D., Wang D., 2017. Impacts of polypropylene glycol (PPG) additive and $\mathrm{pH}$ on tribological properties of water-based drilling mud for steel-steel contact. Tribology International, 110: 318-325. DOI: 10.1016/j.triboint.2017.02.025.

Xu J., Qiu Z., Huang W., Zhao X., 2017. Preparation and performance properties of polymer latex SDNL in water-based drilling troublesome shale formations. Journal of Natural Gas Science and Engineering, 37: 462-470. DOI: 10.1016/j.jngse.2016.11.064.

Zamora M., Roy S., Slater K.S., Troncoso J.C., 2013. Study on the Volumetric Behavior of Base Oils, Brines, and Drilling Fluids Under Extreme Temperatures and Pressures. SPE 160029PA, SPE Drilling and Completion, 28(3): 278-288. DOI: 10.2118/160029-MS.

Zhang Q., Jia W., Fan X, Liang Y., Yang Y., 2015. A review of the shale wellbore stability mechanism based on mechanical-chemical coupling theories. Petroleum, 1: 91-96. DOI: 10.1016/j. petlm.2015.06.005.

Zhao X., Qiu Z., Huang W., Wang M., 2017. Mechanism and method for controlling low-temperature rheology of water-based drilling fluids in deep water drilling. Journal of Petroleum Science and Engineering, 154: 405-416. DOI: 10.1016/j.petrol.2017.04.036.

Zhu D., Jirui Hou, Qi Wei, Yuguang Chen, Kewen Peng, 2017. Development of a High-Temperature Resistant Polymer Gel System for Conformance Control in Jidong Oilfield. Society of Petroleum Engineers. DOI: 10.2118/186235-PA.

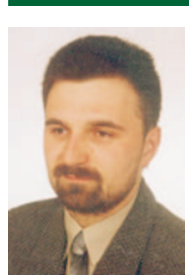

Dr inż. Grzegorz ZIMA

Adiunkt w Zakładzie Technologii Wiercenia Instytut Nafty i Gazu - Państwowy Instytut Badawczy ul. Lubicz 25 A

31-503 Kraków

E-mail: grzegorz.zima@inig.pl

\section{OFERTA BADAWCZA ZAKŁADU PALIW I PROCESÓW KATALITYCZNYCH}

opracowywanie, rozwijanie i wdrażanie technologii produkcji LPG, benzyn silnikowych, paliw lotniczych, olejów napędowych, biopaliw I i Il generacji oraz olejów opałowych, prowadzenie nadzoru technologicznego nad opracowanymi i wdrożonymi technologiami;

ocena i atestacja komponentów paliwowych, w tym biokomponentów I i ll generacji oraz komponentów ze źródet alternatywnych;

opracowywanie technologii uszlachetniania paliw i biopaliw silnikowych oraz olejów opatowych i rozpuszczalników, dobór odpowiednich dodatków uszlachetniających;

wykonywanie badań i ekspertyz dotyczących jakości paliw i biopaliw silnikowych, olejów opałowych, rozpuszczalników i ich komponentów oraz ocena zgodności ze specyfikacią;

ocena skażenia mikrobiologicznego paliw w systemie produkcji i dystrybucij;

ocena wtaściwości niskotemperaturowych olejów napędowych i opałowych;

badania stabilności pozostałościowych olejów opałowych i kompatybilności ich komponentów;

opracowywanie, rozwijanie i wdrażanie nowych wodorowych procesów katalitycznych, ocena testowa i procesowa katalizatorów stosowanych w przemyśle rafineryjnym w procesach zeoformingu, hydroodsiarczania, hydrorafinacii i katalitycznego odparafinowania:

ocena jakości biomasy stałej oraz opracowywanie technologii termicznego jej przetwarzania wraz z oceną właściwości produktów procesu;

ocena oddziatywania na środowisko paliw, biopaliw i innych produktów pochodzących z przemystu rafineryinego i petrochemicznego w oparciu o analize cyklu życia produktu (LCA, carbon footprint, water footprint);

ocena produktu/technologii ze względu na zgodność z kryteriami zrównoważonego rozwoju i ideą „circular economy";

ocena ekoefektywności zgodnie z normą EN ISO 14045.

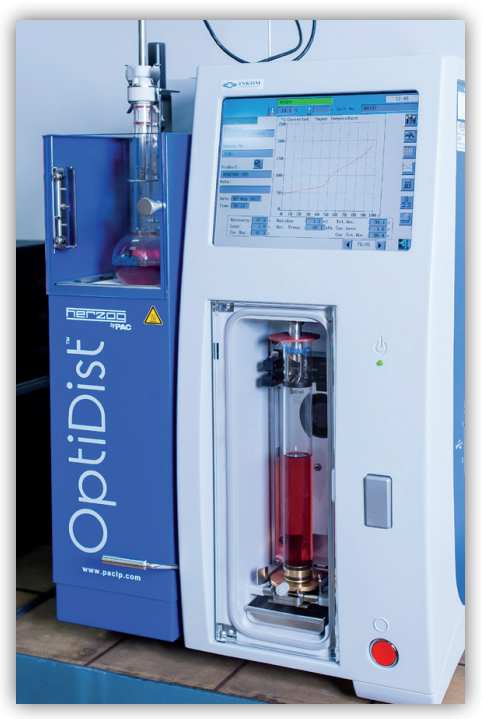

Kierownik: dr inż. Jan Lubowicz Adres: ul. Łukasiewicza 1, 31-429 Kraków Telefon: 126177550 Faks: 126177522 E-mail:jan.lubowicz@inig.pl 